\title{
Faktor Determinan Pemilihan Makanan Jajanan pada Siswa Sekolah Dasar
}

\author{
Determinant Factors in Snack Choice of Elementary School Students
}

\author{
Yohanes Kristianto, Bastianus Doddy Riyadi, Annasari Mustafa
}

Jurusan Gizi Politeknik Kesehatan Kementerian Kesehatan Malang

\begin{abstract}
Abstrak
Makanan jajanan pada siswa sekolah masih banyak yang bermutu rendah sehingga keterampilan anak dalam memilih memegang peran penting dalam mendapatkan jajanan yang sesuai dengan kebutuhannya. Penelitian ini bertujuan untuk menilai mutu jajanan siswa sekolah dan mengidentifikasi faktor-faktor yang menentukan pemilihan jajanan. Penelitian dilakukan dengan menggunakan desain cross sectional pada 120 siswa sekolah dasar di Kota Batu yang dipilih secara purposif pada bulan September hingga Desember 2009. Mutu jajanan sekolah diperiksa di laboratorium. Siswa diminta untuk menjawab 28 pertanyaan tentang pemilihan jajanan. Data yang diperoleh diolah dan dianalisis dengan uji analisis faktor. Hasil penelitian menunjukkan bahwa pada umumnya jajanan pada siswa sekolah mengandung energi di bawah standar (300 Kkal/porsi). Komposisi bahan penyusun jajanan kurang bervariasi. Sebagian besar jajanan $(71,4 \%)$ mengandung formalin. Faktor utama yang menentukan pemilihan jajanan di sekolah mencakup variabel harga, hadiah, ukuran porsi, aroma, dan kebebasan menentukan pilihan sendiri. Dari hasil penelitian dapat disimpulkan bahwa kandungan gizi dan keamanan jajanan anak sekolah perlu ditingkatkan. Determinan utama pemilihan jajanan didominasi aspek harga, hadiah, dan cita rasa. Untuk membuat jajanan yang bergizi dan aman disarankan pembuatan dilakukan dengan menggunakan bahan pangan dan teknologi lokal. Selain itu, juga diperlukan penegakan hukum terkait dengan penggunaan bahan berbahaya dalam jajanan siswa sekolah. Kata kunci: Jajanan, kandungan gizi, siswa sekolah
\end{abstract}

\section{Abstract}

Snacks of poor qualities which still predominate foods sold in school highlights the importance of skill in choosing healthy foods. This research was aimed to examine the quality of snack and determine factors that contribute to children's food choice. The study was conducted using cross sectional design on purposefully selected 120 school children from four elementary schools in Kota Batu in September to December 2009. School snacks were collected for laboratory analyses. The children were asked to the extent they agree or disagree with 28 questions on snack choice. The collected data were analysed using factor analysis test. The study revealed that the energy content of the snacks was generally below standard (300 Kcal/serving). The snacks were in most cases made of less diverse food ingredients while $71.4 \%$ samples contained formaldehyde. The children choice to snacks were primarily determined by factor including price, gimmick, serving size, flavor, and freedom to choose their own snacks. It is concluded that both snack quality and safety should be improved. Determining factors to snack choice mainly cover price, gimmick, and food sensory qualities. Snacks made of local mixed-ingredients should be promoted to decrease the price while regulations on providing better and safer foods should be seriously enforced.

Keywords: Snacks, nutrition ingredients, school children

\section{Pendahuluan}

Makanan jajanan sekolah berkontribusi signifikan mencapai $20 \%-31,1 \%$ kebutuhan energi harian anak.1,2 Namun, hampir setengah (45\%) jajanan yang tesedia di sekolah tidak memenuhi persyaratan kesehatan akibat kandungan bahan berbahaya dalam jajanan. Data kejadian luar biasa keracunan pangan menunjukkan bahwa $19 \%$ kasus keracunan terjadi di sekolah dan sekitar 78,57\% menimpa anak sekolah dasar. ${ }^{2}$ Peredaran jajanan di sekolah melibatkan banyak pihak meliputi produsen, penjual, manajer sekolah, siswa, dan pemerintah yang pemegang regulasi. Untuk mencapai target makanan jajanan yang sehat, dalam Aksi Nasional

Alamat Korespondensi: Yohanes Kristianto, Jurusan Gizi Politeknik Kesehatan Kementerian Kesehatan Malang, Kampus Utama, Jl. Besar Ijen 77 C Malang Jawa Timur 65112, Hp.081334718541, e-mail: ykristianto@hotmail.com 
Pangan Jajanan Anak Sekolah yang diinisiasi Badan Pengawas Obat dan Makanan digunakan lima strategi yang melibatkan berbagai pihak tersebut. Kelima strategi tersebut meliputi perkuatan program Aksi Nasional Pangan Jajanan Anak Sekolah, peningkatan "awareness" komunitas sekolah, peningkatan kapasitas sumber daya pangan jajanan anak sekolah, modeling dan replikasi kantin sekolah, dan optimalisasi manajemen Aksi Nasional Pangan Jajanan Anak Sekolah. ${ }^{3}$ Target aksi tersebut adalah meningkatkan proporsi pangan jajanan anak sekolah yang memenuhi syarat keamanan, mutu, dan gizi dari 56\% pada tahun 2010 menjadi $90 \%$ dalam tiga tahun antara $2012-2014 .^{4}$

Hampir semua anak sekolah dasar mempunyai kebiasaan jajan. Keterampilan anak dalam memilih jajanan di sekolah merupakan faktor kritis untuk mendapatkan makanan yang sesuai kebutuhan dan memenuhi syarat kesehatan. Beberapa penelitian dilakukan untuk mengetahui perilaku jajan anak, tetapi belum ada penelitian yang mengkaji faktor determinan membeli jajanan secara analisis faktorial. Tujuan penelitian ini untuk mengidentifikasi faktor determinan yang menentukan keputusan anak membeli makanan jajanan di sekolah yang berguna sebagai data dasar penyusunan strategi pengelolaan jajanan sehat di sekolah.

\section{Metode}

Penelitian observasional deskriptif eksploratif ini menggunakan desain studi cross sectional dengan pengumpulan data dalam waktu relatif bersamaan. Populasi penelitian adalah siswa sekolah dasar di Kota Batu dengan sampel siswa SD Tlekung I, SD Torongrejo I, SD Pesanggrahan I, dan SD Pandanrejo I yang duduk di kelas IV, V, dan VI. Jumlah sampel yang ditarik dari setiap sekolah dasar dengan metode purposif adalah 120 anak. Kriteria inklusi meliputi anak sekolah dasar yang mempunyai kantin atau penjual makanan di sekitar sekolah di wilayah Kota Batu. Anak dapat berkomunikasi dengan baik dalam merespons pertanyaan di kuesioner. Terdapat siswa yang mengalami masalah kesehatan terkait konsumsi jajanan. Kriteria eksklusi adalah sekolah yang mempunyai kantin percontohan di bawah bimbingan instansi kesehatan.

Data yang dikumpulkan meliputi gambaran umum sekolah yang dikumpulkan melalui wawancara dengan kepala sekolah, data nilai gizi makanan yang dikumpulkan dengan menganalisis zat gizi, data kandungan formalin, rhodamin B, dan boraks yang diketahui dengan menganalisis contoh jajanan di sekolah sasaran secara kualitatif, data determinan pembelian makanan jajanan yang meliputi unsur harga, cita rasa makanan, bentuk, keberadaan hadiah, komposisi bahan penyusun, suhu penyajian, keamanan, keramahan penjual, dan peran orang lain dalam pemilihan. Data dikumpulkan melalui wawancara pada siswa sekolah menggunakan kuesioner yang berisi 28 pertanyaan. Data gambaran umum sekolah dan sampel, data mutu makanan dianalisis secara deskriptif, faktor yang memengaruhi pemilihan jajanan diolah dengan uji statistik analisis faktor.

\section{Hasil}

\section{Gambaran Lokasi dan Sampel}

Sekolah dasar yang disertakan dalam penelitian ini berada di wilayah perkotaan dengan tipologi geografi daerah pegunungan berhawa sejuk. Penjual jajanan keliling menjajakan makanan dan minuman setiap hari di lingkungan sekitar sekolah. Pihak sekolah tidak mempunyai aturan khusus untuk mengatur aktivitas penjual tersebut. Produk jajanan yang ditawarkan adalah buatan sendiri dan produk pihak lain. Pembuat jajanan sangat bervariasi, mulai dari produsen jenis rumah tangga sampai industri makanan pabrikan. Di sekolah juga terdapat kantin sederhana yang menjual makanan serupa dengan jajajan yang ditawarkan pedagang keliling.

Siswa yang terpilih menjadi sampel pada umumnya adalah perempuan berumur $9-13$ tahun yang terbiasa membawa uang saku yang sebagian besar digunakan untuk jajan ketika istirahat. Sebagian besar anak $(64,2 \%)$ membawa makanan bekal (Tabel 1).

\section{Karakteristik Jajanan}

Makanan jajanan anak sekolah yang diteliti adalah 53 jenis yang dikelompokkan dalam jajanan tradisional dan jajanan pabrik. Jajanan tradisional yang disiapkan di tingkat rumah tangga atau industri kecil dengan teknik pemasakan yang lazim digunakan sehari-hari. Sebagian besar makanan jajanan anak sekolah di Kota Batu termasuk dalam kelompok makanan jajanan tradisional yang didistribusikan tanpa merek dagang dan ijin edar. Termasuk dalam kelompok ini antara lain cilok, bakso goreng, siomay, pangsit, batagor, dan sosis. Sedangkan

Tabel 1. Karakteristik Sampel dan Kebiasaan Jajan

\begin{tabular}{llcc}
\hline Variabel & Kategori & Nilai & Persentase (\%) \\
\hline Usia (tahun) & Rentang & $9-13$ & - \\
& Rata-rata & 10,4 & - \\
& Standar deviasi & 1,1 & - \\
Uang saku (rupiah) & Rentang & $1.000-5.000$ & - \\
& Rata-rata & 2.175 & - \\
& Standar deviasi & 841,8 & - \\
Jajan/hari (rupiah) & Rentang & $500-4.000$ & - \\
& Rata-rata & 1.479 & - \\
\multirow{2}{*}{ Frekuensi jajanan } & Standar deviasi & 662,3 & - \\
& Tiap hari & 113 & 94,2 \\
& 3-4 kali seminggu & 2 & 1,7 \\
Waktu jajan & 1 - 2 kali seminggu & 5 & 4,2 \\
& Istirahat & 93 & 77,5 \\
\multirow{2}{*}{ Jenis kelamin } & Pulang sekolah & 1 & 0,8 \\
& Tidak tentu & 26 & 21,7 \\
& Laki-laki & 50 & 41,7 \\
& Perempuan & 70 & 58,3 \\
\hline
\end{tabular}


jajanan pabrikan dibuat oleh industri makanan pabrik dan diedarkan dengan menggunakan label makanan pada kemasannya.

Kandungan energi jajanan sekolah di Kota Batu dikelompokkan dalam tiga kategori meliputi $150-200$ Kkal, 100 - 149 Kkal, dan <100 Kkal (Tabel 2). Bahan penyusun jajanan di sekolah dasar Kota Batu umumnya menggunakan kombinasi bahan dasar yang kurang beragam, seperti pisang goreng, nasi goreng, tempe menjes, es lilin, dan sirup. Kebanyakan makanan jajanan pabrik hanya menyantumkan komposisi bahan tanpa disertai informasi kandungan gizi pada label. Produk yang tidak mencantumkan informasi gizi antara lain adalah Mie Remez ${ }^{\circledR}$, Powder drink ${ }^{\circledR}$, kerupuk Top ten ${ }^{\circledR}$, snack Mr. Topan ${ }^{\circledR}$, opak chips Opapop ${ }^{\circledR}$ (rasa pedas manis), kerupuk Juara $^{\circledR}$, jelly jelly Iri ${ }^{\circledR}$, minuman rasa buah Ekso $\mathrm{Cool}^{\circledR}$. Sebagian kecil jajanan kemasan dengan label menyantumkan informasi nilai gizi (Tabel 3).

\section{Kandungan Bahan Berbahaya dalam Jajanan}

Banyak jajanan anak sekolah di Kota Batu tidak memenuhi syarat keamanan karena penggunaan bahan berbahaya yang terlarang. Bahan berbahaya tersebut terbanyak adalah formalin $(71,4 \%)$, boraks $(23,5 \%)$, dan rhodamin B (18,5\%) (Tabel 4).

\section{Analisis Faktor Determinan Pembelian Jajanan}

Analisis faktor terhadap 28 variabel yang dikumpulkan membentuk sembilan faktor, lima di antaranya tidak dapat diandalkan sehingga disertakan dalam model analisis. Empat faktor determinan pemilihan makanan jajanan anak yang dapat diandalkan disajikan pada Tabel 5 . Korelasi keempat faktor tersebut adalah 0,$8 ; 0,7 ; 0,6$; dan 0,5 . Nilai korelasi setiap variabel terhadap faktor merupakan dasar untuk memasukkan suatu variabel dalam kuesioner ke dalam faktor yang terbentuk dalam analisis. Suatu variabel dimasukkan dalam suatu faktor jika angka korelasi terhadap faktornya cukup kuat $(>0,5)$.

\section{Pembahasan}

Semua anak yang membawa uang saku ke sekolah mengindikasikan peluang besar anak untuk belanja. Hampir seluruh siswa membeli makanan jajanan sekolah setiap hari. Makanan jajanan tampaknya merupakan
Tabel 2. Kandungan Energi Jajanan Tradisional per Porsi

\begin{tabular}{|c|c|}
\hline Energi & Jenis Makanan Jajanan \\
\hline $150-200 \mathrm{Kkal}$ & $\begin{array}{l}\text { Gorengan pangsit, weci, roti goreng panjang, tempura mi, } \\
\text { roti goreng bunga, donat, gorengan isi tempura, cilok go- } \\
\text { reng, es cendol }\end{array}$ \\
\hline $100-149 \mathrm{Kkal}$ & $\begin{array}{l}\text { Sosis bulat, bakwan, roti goreng bulat, cilok, pisang go- } \\
\text { reng kipas, mi kering bumbu merah, roti pisang selai, mi } \\
\text { kering, tahu pentol, kacang goreng, tempura crispy, tape } \\
\text { goreng, tempura bentuk kelinci, gorengan mi, ketela go- } \\
\text { reng, tempura spiral, stik pedas, goreng-cilok, gorengan, } \\
\text { makaroni pedas, gorengan tabur meses, pecel, kerupuk } \\
\text { merah, susu, juruh }\end{array}$ \\
\hline$<100 \mathrm{Kkal}$ & $\begin{array}{l}\text { Nasi goreng, mie basah, marning jagung, sosis bulat me- } \\
\text { rah, sosis spiral warna merah, tempura lingkaran, tempu } \\
\text { ra spiral coklat, tahu isi, kacang kulit, tahu gembos, tahu } \\
\text { gembos-cilok, telur goreng, pop corn, tahu putih, pentol- } \\
\text { cilok, batagor, siomay-cilok, pentol, kerupuk pangsit, ke- } \\
\text { rupuk "camilan rasa bawang", kedelai bawang "MMM", } \\
\text { kerupuk panjang, menjes, kacang kapri, kerupuk, tempu- } \\
\text { ra bentuk kotak, melon, anggur, tempe goreng, tempe go- } \\
\text { reng tepung, tempe menjes, susu kedelai, es hijau, es ora- } \\
\text { nye, es kuning, es sirup pink, es kacang hijau, susu kede- } \\
\text { lai, gulali, minuman teh }\end{array}$ \\
\hline
\end{tabular}

bagian penting dalam memenuhi kebutuhan gizi harian anak. Hampir semua anak usia sekolah (95 - 96\%) melakukan jajan. ${ }^{5}$ Penelitian di Kota Semarang bahkan menunjukkan rata-rata frekuensi jajan anak sekolah dasar antara 2 - 3 kali setiap hari yang terkait dengan rendahnya pengawasan pihak sekolah dan uang saku yang besar. ${ }^{6}$

Kandungan energi makanan jajanan per porsi yang beredar di sekolah dasar Kota Batu pada umumnya lebih rendah dari nilai yang dipersyaratkan untuk makanan tambahan anak sekolah (300 Kkal). ${ }^{7}$ Namun, sebagian kecil jajanan mendekati persyaratan gizi tersebut meliputi pangsit ( 5 biji), weci, roti goreng, dan donat. Untuk mendapatkan jumlah energi yang mendekati standar, diperlukan lebih dari satu porsi saji. Hal tersebut sulit dilakukan karena porsi yang besar membuat anak tidak mampu menghabiskannya. Selain itu, harga dua porsi makanan dari jenis yang sama atau berbeda mungkin tidak terjangkau, mengingat uang saku siswa yang rendah. Banyak siswa yang membawa bekal $(64,2 \%)$ dapat meminimalkan kekurangan asupan gizi dari makanan jajanan. Bekal yang dibawa siswa berupa nasi dan mi dengan lauk. Kebiasaan membawa bekal sangat

Tabel 3. Kandungan Gizi Jajanan Kemasan

\begin{tabular}{lccccc}
\hline Nama Produk & $\begin{array}{c}\text { Takaran Saji/ } \\
\text { per Kemasan }\end{array}$ & $\begin{array}{c}\text { Energi } \\
\text { (Kkal) }\end{array}$ & $\begin{array}{c}\text { Lemak } \\
\text { (gr) }\end{array}$ & $\begin{array}{c}\text { Protein } \\
\text { (gr) }\end{array}$ & $\begin{array}{c}\text { Karbohidrat } \\
\text { (gr) }\end{array}$ \\
\hline Jajanan dua warna (rasa sambal balado) & $7 \mathrm{~g} / 1$ & 40 & 2 & 1 & 4 \\
Permen susu lolipop & $9 \mathrm{~g} / 1$ & 35 & 0 & 0 & 8 \\
Minuman jus instan rasa stroberi & $8 \mathrm{~g} / 1$ & 40 & 0 & 0 & 8 \\
Minuman segar instan rasa buah & $12 \mathrm{~g} / 1$ & 45 & 0 & 0 & 12 \\
Milkshake pop ice (stroberi) & $25 \mathrm{~g} / 1$ & 100 & 0,5 & 1 & 23 \\
Minuman dingin instan (rasa apel) & $8 \mathrm{~g} / 1$ & 30 & 0 & 0 & 8 \\
\hline
\end{tabular}


Tabel 4. Bahan Terlarang dalam Jajanan

\begin{tabular}{lccc}
\hline \multirow{2}{*}{ Jenis Pemeriksaan } & Sampel & \multicolumn{2}{c}{ Hasil Positif } \\
\cline { 3 - 4 } & & $\mathbf{n}$ & $\%$ \\
\hline Formalin & 21 & 15 & 71,4 \\
Boraks & 17 & 4 & 23,5 \\
Rhodamin B & 27 & 5 & 18,5 \\
\hline
\end{tabular}

Tabel 5. Faktor-faktor Determinan Pembelian Jajanan

\begin{tabular}{clc}
\hline Faktor & Variabel dalam Faktor & Nilai Korelasi \\
\hline \multirow{2}{*}{1} & Harga murah & 0.74 \\
& Ada hadiah & 0.72 \\
& Porsi besar & 0.71 \\
& Aroma enak & 0.56 \\
\multirow{2}{*}{2} & Kebebasan memilih & 0.53 \\
3 & Peran teman & 0.79 \\
& Rasa asin & 0.68 \\
4 & Warna menarik & 0.50 \\
& Tekstur empuk & 0.75 \\
& Rasa gurih & 0.64 \\
\hline
\end{tabular}

membantu menurunkan masalah kekurangan asupan gizi selama siswa berada di sekolah.

Bahan untuk makanan jajan yang kurang bervariasi berakibat pada keragaman zat gizi yang rendah, makanan jajanan yang padat gizi hanya dapat dibuat dari bahan yang beragam sehingga kekurangan suatu jenis zat gizi di satu bahan dapat dikompensasi dari bahan lain. Kombinasi penggunaan bahan lokal serealia dan kacangkacangan merupakan kombinasi yang baik karena asam amino yang saling melengkapi. Kacang-kacangan umumnya banyak mengandung lisin tetapi rendah metionin, sedangkan serealia umumnya tinggi metionin tetapi rendah lisin. Penggunaan bahan penyusun jajanan yang kurang bervariasi menjadi ancaman bagi pemenuhan zat gizi anak. Penelitian di Jawa Barat, menemukan jajanan yang miskin zat gizi mikro berpengaruh terhadap status gizi anak. ${ }^{8}$

Pada penelitian ini, keamanan makanan yang menjadi isu penting khusus anak sekolah adalah variabel dalam faktor yang tidak dapat diandalkan dalam model. Hal tersebut mengindikasikan kebutuhan peningkatan pemahaman siswa. Hasil tes formalin, boraks, dan rhodamin B yang positif mengindikasikan kebutuhan penelitian lebih lanjut untuk mengidentifikasi tahapan dalam rantai produksi penambahan bahan terlarang tersebut. Formalin sangat mudah diserap melalui saluran pernapasan dan menyebabkan berbagai gangguan kesehatan. Formalin dianggap tidak lagi berbahaya karena dalam tubuh dapat diuraikan. Dalam tubuh formaldehid diuraikan menjadi asam format oleh enzim formaldehida dehidrogenase. Bahan tersebut selanjutnya dikeluarkan lewat urine dan sebagian melalui nafas setelah dirubah menjadi $\mathrm{CO}_{2}$. Namun komponen formaldehid yang tidak dimetabolisme membentuk ikatan silang yang stabil dengan protein DNA. Ikatan silang ini yang diduga bertanggung jawab atas kekacauan pada sistem informasi genetika yang pada gilirannya memicu terjadinya kanker dan mutasi genetik. Jika gen-gen yang rusak itu diturunkan maka lahirlah generasi yang mempunyai kecacatan genetik. ${ }^{9}$

Harga merupakan salah satu variabel utama yang menentukan pemilihan jajanan anak sekolah dasar Kota Batu. Pengeluaran uang saku anak untuk jajan (50 $80 \%$ ) yang tergolong tinggi, mengindikasikan jajanan merupakan prioritas. Nilai rata-rata pengeluaran jajanan siswa yang mendekati Rp1.500,00 dari harga jajanan setempat, jenis jajanan yang dapat dibeli anak berada pada kisaran $1-2$ jenis. Untuk menunjang aktivitas fisik yang tinggi di sekolah, seharusnya anak memilih jajanan energi tinggi (150 - $200 \mathrm{Kkal})$. Keterampilan memilih jajanan yang rendah berakibat pada pemilihan jajanan rendah energi seperti buah, minuman, dan aneka kerupuk. Harga total dan harga satuan buah-buahan lebih rendah daripada jajanan, tetapi harga energi buah lebih mahal. ${ }^{10}$ Dengan jumlah uang yang sama, asupan energi yang diperoleh lebih sedikit, sehingga jajanan tidak berkonstribusi bermakna pada asupan total harian anak.

Variabel penting lain adalah berbagai hadiah yang merupakan alat promosi produsen biaya tinggi. Biaya untuk promosi makanan jajanan anak dan remaja (2 - 17 tahun) di Amerika tahun 2009 mencapai 123,3 juta dolar atau $15,4 \%$ dari total biaya pemasaran makanan tersebut. Total biaya pemasaran sedikit lebih rendah daripada tahun sebelumnya, tetapi teknik pemasaran semakin intensif mengintegrasikan media tradisional dengan internet, penggunaan karakter dalam beragam media digital untuk menjangkau anak dan remaja. ${ }^{11}$ Pada penelitian ini, hadiah dan pembelian jajanan anak sekolah dasar berkorelasi kuat, menunjukkan besar harapan siswa mendapatkan nilai lebih dari jajanan. Hal tersebut dapat mengalihkan perhatian untuk membeli makanan yang lebih dibutuhkan.

Porsi makanan yang besar juga menjadi daya tarik tersendiri bahwa besar porsi jajanan mencerminkan kemampuan memberikan rasa kenyang dan asupan gizi yang lebih. Namun hal tersebut tidak selalu benar. Jajanan tinggi lemak meskipun porsi kecil dapat mengandung energi yang lebih besar daripada jajanan yang didominasi karbohidrat atau protein. Masih banyak jajanan di sekolah yang mengandung rendah energi tiap porsi sehingga tidak memenuhi kebutuhan gizi harian anak. Pemberian jajanan di sekolah yang memenuhi $30-50 \%$ kebutuhan energi harian anak selama empat bulan terbukti berdampak positif pada pertumbuhan linear, penurunan angka kesakitan, dan perbaikan status vitamin B12 anak sekolah. ${ }^{12}$ Untuk menghindari salah tafsir kandungan 
gizi berdasarkan porsi, ukuran porsi jajanan anak sekolah harus sesuai standar (300 Kkal/porsi). Hal tersebut dilakukan menggunakan berbagai bahan yang padat gizi seperti tepung terigu atau seralia, tepung umbi-umbian, mentega, minyak nabati, kacang-kacangan, telur, dan susu. Kota Batu termasuk sentral penghasil susu sapi dan kentang berpotensi menekan biaya produksi. Pembuatan jajanan yang baik, setiap porsi harus mengandung energi dan protein yang sama, meskipun ukuran porsi beragam.

Aroma makanan merupakan atribut mutu utama yang menentukan apakah seseorang menerima atau menolak makanan. ${ }^{13}$ Beragam aroma makanan ditemukan pada berbagai jajanan sekolah seperti pada minuman, kerupuk, makaroni, dan mi instan. Penggunaan aroma makanan merupakan strategi penjual untuk menyediakan jajanan dengan beragam pilihan, mengingat komposisi bahan jajanan yang digunakan sama. Penggunaan aroma makanan dapat meningkatkan perasaan kenyang seperti yang ditemukan penelitian aroma stroberi multikomponen pada produk yoghurt. ${ }^{14}$ Efek kenyang berhubungan dengan peningkatan stimulasi sensoris yang kompleks. Banyak ragam jajanan yang ditawarkan di sekolah, perlu menetapkan penggunaan aroma jajanan terpilih sehingga dapat menghindari kesalahan memilih. Hal tersebut berhubungan dengan kemampuan siswa mengestimasi makanan yang memenuhi rasa kenyang. ${ }^{15}$

Penjaja makanan di lingkungan sekolah menjual jajanan dengan warna yang menyolok seperti es sirup, sosis, mi, dan es lilin dan warna makanan jajanan yang ditawarkan adalah merah, kuning dan hijau terang. Sampel yang mengandung rhodamin B tergolong tinggi $(18,5 \%)$ mengindikasikan praktik produksi yang tidak baik. Penelitian makanan jajanan sekolah di Jakarta dan Sukabumi menemukan sekitar $74,1 \%$ penjaja yang diteliti melakukan praktik keamanan pangan yang rendah, termasuk penggunaan bahan tambahan pangan yang berbahaya. ${ }^{16}$ Rhodamin B merupakan bahan kimia yang murah dengan warna sangat menarik, tetapi membahayakan kesehatan. Rhodamin B yang diserap dengan baik pada saluran pencernaan dapat menyebabkan iritasi saluran cerna. Pajanan yang lama menyebabkan kelainan fungsi hati atau kanker. Toksisitas rhodamin B dilaporkan orl-rat LDLO $500 \mathrm{mg} / \mathrm{kg}$.

Variabel keempukan dan rasa gurih adalah faktor penting lain pemilihan makanan jajanan. Keempukan merupakan komponen "palatability", sedangkan rasa gurih merupakan unsur "basic taste". Komponen palatability mencakup unsur tekstur, temperatur, warna, bentuk, dan sound. Basic taste terdiri atas unsur sweet, sour, salty, bitter, dan umami. Rasa gurih dipersepsi sama dengan rasa asin dengan alasan untuk menimbulkan rasa gurih diperlukan garam. Namun, pada penelitian ini variabel rasa gurih dan asin dipisahkan karena sel reseptor asin dan gurih berbeda. Reseptor untuk senyawa garam antara lain kanal ion dalam mikrovili yang memungkinkan ion garam langsung masuk ke dalam sel. Akumulasi ion sodium menyebabkan depolarisasi yang mengakibatkan ion $\mathrm{Ca}^{2+}$ masuk dalam sel. Selanjutnya, ion kalsium menyebabkan pengeluaran sinyal neuotransmiter yang diterima oleh sel syaraf dan meneruskannya ke otak. ${ }^{17}$

Upaya perbaikan mutu jajanan anak sekolah dasar Kota Batu dapat dilakukan dengan meningkatkan kemampuan pengelolaan jajanan sekolah menerapkan standar gizi dan keamanan makanan, dengan pendampingan tenaga ahli dan penegakan peraturan. Upaya pendampingan terbukti efektif meningkatkan mutu penggunaan bahan jajanan. ${ }^{18}$ Selain itu, perlu membekali anak dengan keterampilan memilih jajanan yang baik dengan membentuk kelompok siswa. Teman sebaya merupakan variabel penting dalam memilih jajanan. Siswa model perlu dilatih secara khusus dan berkesinambungan sehingga pengaruh kepada siswa lainnya dapat bermakna.

\section{Kesimpulan}

Kandungan gizi makanan jajanan anak sekolah dasar masih di bawah ketentuan kandungan gizi kudapan. Kandungan gizi makanan jajanan kemasan sulit untuk diperkirakan karena tidak terdapat informasi gizi pada label. Makanan jajanan tradisional umumnya menggunakan bahan yang kurang bervariasi. Sejumlah besar makanan jajanan anak sekolah masih mengandung bahan berbahaya. Sebanyak 15 jajanan $(71,4 \%)$, 4 jajanan $(23,5 \%)$ dan 5 jajanan $(18,5 \%)$ positif mengandung berturut-turut formalin, boraks, dan rhodamin B. Anak sekolah dasar dalam memilih makanan jajanan mempertimbangkan empat faktor utama. Faktor pertama, harga murah, ada hadiah, proporsi besar, dan aroma menarik. Faktor kedua, meliputi variabel tingkat keempukan makanan dan rasa yang gurih. Faktor ketiga, pengaruh teman. Faktor keempat mencakup daya tarik warna dan rasa jajanan yang cenderung asin.

\section{Saran}

Untuk meningkatkan mutu gizi dan menekan harga jual jajanan sekolah disarankan memaksimalkan penggunaan bahan baku dan teknologi yang tersedia di daerah setempat. Pemilihan bahan perlu mempertimbangkan kombinasi penggunaan bahan yang bervariasi dalam jumlah yang cukup sehingga dapat memenuhi standar gizi jajanan sekolah.

\section{Daftar Pustaka}

1. Haslina, Haryati S. Sumbangan makanan jajanan anak sekolah dasar terhadap asupan energi dan protein di SDN Lamper Kidul 02 Semarang. Jurnal Pengembangan Rekayasa Teknologi. 2012; 14(2): 132-40. 
2. Direktorat Surveilan dan Penyuluhan Keamanan Pangan. Food watch. Jakarta: Badan Pengawas Obat dan Makanan Republik Indonesia; 2009.

3. Badan Pengawas Obat dan Makanan. Komitmen dan kemandirian komunitas sekolah sukseskan aksi Nasional PJAS. InfoPOM. 2012: 3-6.

4. Badan Pengawas Obat dan Makanan. Rangkaian kegiatan peduli PJAS 2011. Warta POM. 2011.

5. Muhilal, Damayanti D. Gizi seimbang untuk anak usia sekolah dasar. Dalam: Soekirman, Susana H, Giarno M, Lestari Y, editors. Hidup sehat: gizi seimbang dalam siklus kehidupan manusia. Jakarta: Primamedia Pustaka; 2006. p. 90-105.

6. Saputra AD. Hubungan tingkat pengetahuan dengan perilaku siswa kelas sekolah dasar. Unnes Journal of Public Health. 2012; 1(1): 1-7.

7. Direktorat Pendidikan Madrasah. Pedoman pelaksanaan penyediaan makanan tambahan anak sekolah (PMT-AS) bagi siswa RA dan MI Tahun 2012. Jakarta: Direktorat Jenderal Pendidikan Islam Kementerian Agama Republik Indonesia; 2012.

8. Sekiyama M, Roosita K, Ohtsuka R. Snack foods consumption contributes to poor nutrition of rural children in West Java, Indonesia. Asia Pacific Journal of Clinical Nutrition. 2012; 21(4): 558-67.

9. Badan Pengawas Obat dan Makanan. Bahan berbahaya yang dilarang untuk pangan. Jakarta: Badan Pengawas Obat dan Makanan Republik Indonesia; 2006.

10. Lipsky LM. Are energy-dense foods really cheaper? reexamining the relation between food price and energy density1-3. American Journal of Clininical Nutrition. 2009; 90: 1397-401.

11. Leibowitz J, Rosch JT, Ramirez E, Brill J, Ohihausen M. A review of food marketing to children and adolescents: follow-up report [monograph on internet]. US Federal Trade Commission; 2012 [cited 2013 Mar 15]. Available from: http://ftc.gov/os/2012/12/121221foodmarketingreport.pdf.

12. Arsenault JE, Mora-Plazas M, Forero Y, Lopez-Arana S, Marın C, Baylin A, et al. Provision of a school snack is associated with vitamin B-12 status, linear growth, and morbidity in children from Bogota, Colombia. Journal of Nutrition. 2009; 139: 1744-50.

13. Blake A. The learning of human flavour preference. In: Voilley A, Etievant P, editors. Flavour in Food. England: Woodhead Publishing Limited; 2006.

14. Ruijschop RMAJ, Boelrijk AEM, Burgering MJM, Graaf Cd, WesterterpPlantenga MS. Acute effects of complexity in aroma composition on satiation and food intake. Chemical Sense. 2010; 35: 91-100.

15. Hardman CA, McCrickerd K, Brunstrom JM. Childern's familiarity with snack foods changes expectation about fullness. American Journal of Clinical Nutrition. 2011; 94: 1196-201.

16. Yasmin G, Madanijah S. Perilaku penjaja pangan jajanan anak sekolah terkait gizi dan keamanan pangan di Jakarta dan Sukabumi. Jurnal Gizi dan Pangan. 2010; 5 (3): 148-57.

17. Smith DV, Margolskee RF. Making sense of taste. Scientific American Inc; 2001.

18. Mozaffarian RS, Wiecha JL, Roth BA, Nelson TF, Lee RM, Gortmaker SL. Impact an organizational intervention design to improve snack and beverage quality in TMCA after-school programs. American Journal of Public Health. 2010; 100: 925-32. 